\title{
In memoriam Jan-Frits Veldkamp (31 March 1941 - 12 November 2017)
}

\author{
P. Baas ${ }^{1}$, P.H. Hovenkamp ${ }^{1}$
}

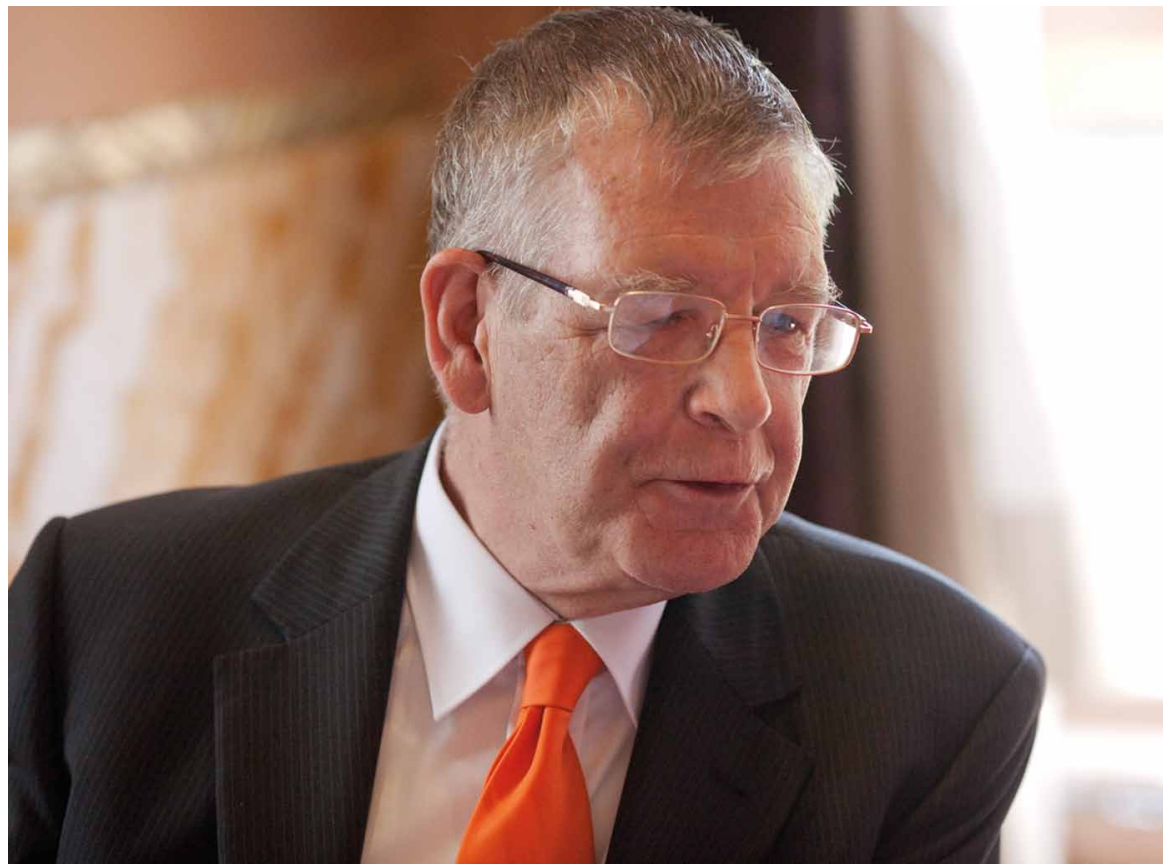

(C) Helen Jones Photography.

Jan-Frits Veldkamp passed away on 12 November 2017 in hospital, in the course of a chemotherapy treatment compromised by an infection. Up to his last weeks, even in hospital, he was actively working to solve taxonomic and nomenclatural problems.

Jan Frederik (Jan-Frits, but mostly JF or JeF for friends) Veldkamp was born in Amsterdam but spent part of his elementary school years in Indonesia. Following his high school (Gymnasium- $\beta$ ) in the Netherlands he studied biology and chemistry for a year at Hamline University, St. Paul, Minnesota on a Fulbright grant. From 1961-1967 he studied biology at Leiden University, where he was destined to embark on a career as a Drosophila geneticist, when in 1965 he was 'snatched' by Professor C.G.G.J. van Steenis from the Genetics Lab to become a demonstrator at the Rijksherbarium. For his MSc projects he studied adaptations to sea dispersal in diaspores of coastal plants, taxonomy of Sarcotheca and Dapania (Oxalidaceae), the effects of temperature on certain attributes of Drosophila melanogaster, and chemotaxonomy of Callitriche (Plantaginaceae). In 1967 he joined the Rijksherbarium staff as a scientific officer, never to leave that institution throughout its metamorphoses as Rijksherbarium/Hortus Botanicus,

\footnotetext{
Naturalis Biodiversity Center, section Botany, P.O. Box 9517, 2300 RA Leiden, The Netherlands;

corresponding author e-mail: peter.hovenkamp@naturalis.nl
}

National Herbarium of the Netherlands, and Botany section of the Naturalis Biodiversity Center. Initially he was to study seed structure of coastal plants, but soon Van Steenis rather bruskly gave him the task to contribute to the Flora Malesiana (FM) effort as a grass taxonomist. In 1973 he defended his PhD thesis on A revision of Digitaria Haller (Gramineae) in Malesia. This was preceded by the treatment of Oxalidaceae for FM in 1972. By his own count, JeF would publish c. 370 papers (and counting), of which c. 220 are taxonomic and systematic contributions, major and minor, mostly on grasses, but a fair number also on representatives of 27 other flowering plant families, most notably Melastomataceae, Asteraceae, Zingiberaceae, Oxalidaceae and Rafflesiaceae. In addition, he submitted 14 nomenclatural proposals and wrote at least 80 reviews, mostly for Flora Malesiana Bulletin. He was the author of 431 names, mostly new combinations resulting from his great interest and expertise on nomenclatural matters, but also including over 115 new taxa (genera, species, subspecies and varieties), testifying to his talents as a keen observer and taxonomist. He maintained an annotated bibliography of his own publications, meticulously cross-referenced to his files, including not only major but also very minor, sometimes highly personal contributions. As this gives an excellent insight in the scrupulous way he worked and kept track of everything, we include this bibliography with only very light editing. 
Throughout his career JeF was an inspiring teacher who taught the course of plant taxonomy for almost 40 years, and also took a leading part in the international taxonomy courses under the auspices of UNICEF and MAB in Bogor in the 1980s. In the process he enthused numerous biology students to pursue taxonomic projects during their MSc programme or to aspire to a career in plant taxonomy. He also (co-)supervised numerous PhD students. He flavoured his lectures with numerous anecdotes, of which he had a great number in stock as a keen biohistorian. And many of his students and colleagues will remember the meticulous care with which he tracked and checked references. "Never believe something just because it is written somewhere, not even if you wrote it yourself" was his motto. His knowledge of the botanical literature and biography was phenomenal and he knew his way in our library and archives better than anyone else.

JeF was a prominent personality in our institute and in the international FM family. As a good classical taxonomist, in excellent command of botanical Latin and botanical nomenclature he generously helped many colleagues at home and abroad to solve nomenclatural puzzles or to obtain literature important for their studies. His dedication to the cause of FM was most visible during the years that he was the Editor of the Flora Malesiana Bulletin, between 1984 and 2008. He solved a chronic problem of shortage of news copy from the international FM Network in the Malesian region by filling literally hundreds of pages himself with very comprehensive bibliographical updates, book reviews, obituaries, points of view, and even short taxonomic papers. The service he thereby provided to isolated colleagues all over the world, in the times before large-scale internet availability and social media, cannot be overestimated. He was really angry and frustrated about the decision of the FM Board in 2007 to abandon the hard-copy publication of the Bulletin, with as a foreseeable consequence its total demise. But, stubbornly, he continued to compile the bibliographies, to the last weeks of his life attending monthly to the newly received journals in our library, and venting his frustration about the increasing numbers of e-subscriptions, which he could not leaf through.

Unfortunately his magnum opus, a family treatment of the grasses for FM, was never finished. This had much to do with the fact that he was easily distracted by the numerous requests for help to solve nomenclatural and other taxonomic puzzles.

JeF was a keen field botanist. In Malesia he took part in expeditions to the mountain ranges of Papua New Guinea (Mt Suckling 1972; Star Mts 1975; Mt Kegum-Mt Burgers 1977; Mt Kerawa 1981 and Mt Fala-Mt Yule-Mt Otto 1989) and East Kalimantan (Gunung Raya 1982/83), but he collected in many other localities in Malesia or on other continents during short trips or holidays. He contributed altogether about 4500 accessions to the $L$ herbarium. He loved the Malesian region, its flora and its people, and he went there many times. Only last year (2017) he visited the Singapore Herbarium twice to complete his contribution on the grasses for the Flora of Singapore. During his travels, he was a prolific and consummate letter-writer, and kept a circle of friends and colleagues informed and amused with accounts of his exploits on an almost daily basis.

As a person JeF was a very kind and helpful colleague, although he sometimes tried to mask that behind a grumpy façade, not unlike that of his great example Professor Van Steenis. Like Van Steenis, he loved to tell botanical stories in monologue form during tea and coffee breaks, but his sense of humour prevented him from taking himself too seriously. He was a driving force behind the addiction of some card players on the Leiden staff to combine lunch with a good game of bridge (including Van Steenis, who was his bridge partner until his death in 1986).

JeF is survived by three daughters and three granddaughters. We will miss his friendship and expertise. The FM community loses another prominent member.

A full bibliography and eponymy is appended.

\section{Eponymy}

\section{Genus}

Veldkampia Ibaragi \& Shiro Kobay., J. Jap. Bot. 83 (2008) 108, t. 1-6. Gramineae

\section{Species}

Artabotrys veldkampii I.M.Turner, Folia Malaysiana 10 (2009) 73, illus. Annonaceae

Biophytum veldkampii A.E.S.Khan, E.S.S.Kumar, S.Binu \& Pushp., Rheedea 8 (1998) 79, t. 1. Oxalidaceae

Bulbophyllum veldkampii J.J.Verm. \& P.O'Byrne, Bulbophyllum Sulawesi (2011) 51, t. *. Orchidaceae

Digitaria veldkampiana B.K.Simon, Austrobaileya 8 (2010) 198. Gramineae

Dimeria veldkampii Kiran Raj \& Sivad., Novon 18 (2008) 183. Gramineae

Glyphochloa veldkampii M.A.Fonseca \& Janarth., Rheedea 13 (2004 '2003') 35-38, illus. Gramineae

Isachne veldkampii K.G.Bhat \& Nagendran, Curr. Sci. 52 (1983) 111, t. 1-4. Gramineae

Ischaemum veldkampii Lasut, Reinwardtia 12 (2006) 257, t. 1. Gramineae

Mnesithea veldkampii Potdar, S.P.Gaikwad, Salunkhe \& S.R.Yadav, Kew Bull. 59 (2005 '2004') 629, illus. Gramineae

Papuacalia veldkampii D.J.N.Hind, Kew Bull. 57 (2002) 693, illus. Compositae

Rubus agricastrorum A.Beek, Gorteria 38 (2016) 225. Rosaceae

Sonerila veldkampiana Ratheesh, Mini \& Sivad., Phytotaxa 110 (2013) 55-60. Melastomataceae 


\section{BIBLIOGRAPHY}

A more or less scientific bibliography of and by J.F. Veldkamp

[The bibliography below was compiled and kept up to date by JeF Veldkamp himself. He also wrote the explanatory introduction, dated 3 July 2010.

We have edited the bibliography only very lightly, where necessary translating a few Dutch words. The numbers before the items refer to the numbered items in JeF's dossier of reprints, mimeographs or xerox copies. This numbering is not always strictly chronological. The unnumbered items at the end of the list are posthumously published.]

To save somebody interested enough to make a bibliography of my scientific works a lot of time, I here present them in a more or less ordered form. There are some - $a$ and -b numbers, in case of reprints, or small notes in larger, heterogeneous articles (e.g., no. 66), or articles that I did not know about until much later (e.g., 364). I did not renumber by date, as the publications have been entered in the order that they were received.

It will be noted that there are quite a number of joint authorships. To avoid any suggestion of parasitizing on my students and colleagues, an explanation seems in order. In many cases students at the Course in Advanced Plant Taxonomy, that I taught or assisted for perhaps 40 years, started a small revision as a training subject. They had put several weeks of tiro's efforts in them, using the Leiden Herbarium's precious material, and the results were sometimes of some scientific interest, so that it seemed a waste not to do something with their reports. However, I usually had to put in such a considerable time and effort to polish them up to an acceptable form, that a co-authorship seemed warranted. After 1982 I was ordered by Kalkman to do so in all cases where a student had done a subject under my guidance (but I got away with articles by Mark Sosef \& Ron de Koning, and the one by Leni Duistermaat, although as much energy had been put in them as with the others). This arrangement had become required, as without a staff member as a co-author, the Herbarium would get no kudos from the University. In later publications I was invited as a co-author because of my transliteration of the original text and my general editorship, nomenclatural advise, literature research, etc., often a lot of work.

With Professor C.G.G.J. van Steenis (I never called him otherwise, although I was his bridge partner for years! Only the elder staff members ever called him Cees) I agree that it was no more than fair that a student should publish the subject of his Bachelor's / Masters' Degree under his / her own name: possibly the only scientific publication on his / her CV. They usually were first authors and must be regarded as responsible for the actual taxonomic work, I for the English and the more general paragraphs, such as the introduction, the nomenclature, and the notes.

In the case of Thonner's Key (48) most of the effort was put into it by Rob Geesink and me, and quite a bit, but not the final touch, was done by Colin Ridsdale on Thonnerstag Abend, Thursday evenings, later on Friday afternoons when Cees Kalkman - finally - saw the scientific value of this effort. Toon Leeuwenberg (WAG) was included in the authorship because he had started a translation, but didn't have the time to do the gigantic job all by himself, although he already had made a contract with a publisher. After the handing over of his translation to us, which had to be rewritten completely for reasons of style and structure, only the chapter on eponymy remained his sole contribution. Besides a good part of the key, I wrote all the introductory chapters, the key to the Monocots, the Glossary, and most of the Index, for which Rob had made in impressive scroll on a huge wooden spindle.

The Manual (88) was for the larger part written by me, too, as one can see. It had started as an idea grown during the work on Thonner's Key to have a companion volume based on Pulle's Compendium and the Manual we had made over the years for the Course at the Herbarium. For the Course in Bogor this was exactly what was needed and De Vogel did little more than formatting the text on his computer.

The Flora Malesiana Bulletin, of which I became Editor in 1983, has as such not been included, although sometimes more than $50 \%$ of my time had gone into compiling the Bibliographies, editing general chapters, contributions, and preparing the indices. It was a sad day when Erik Smets behind my back changed my editorial to include a note that the Bulletin would be available on the Internet, only. I was not informed of this change and I only became aware of it through people who pointed it out to me. This was apparently announced and adopted without further discussion at the Board Meeting of the Flora Malesiana Symposium in Leiden, 2007. Contrary to custom I was not invited to attend that, nor was I informed beforehand of this move. This decision was made, but there was no implementation of how this was going to take place. Thus the FMB died a silent death. Yet, I kept on gathering the data for the Bibliography, just in case. If this was not done, such information could never be retrieved again. At a later meeting of editors of the journals published by the National Herbarium of The Netherlands, Leiden University branch, I was not invited, either, and only afterwards heard that it had taken place. Half-hearted excuses were made by Smets and Marco Roos. Smets, nor Roos, ever inquired about what I was doing. This was otherwise all right by me. Obviously, this lack of interest and commitment caused a lot of resentment on my side.

\section{'Ghost papers'}

The treatment of the Averrhoaceae as attributed to me by Henry Airy Shaw $(1 a, b)$ is incorrect. I did write it, but to show that the 'family' was based on Hutchinson's erroneous observations. (I had to buy my own copy of $1 b$ !)

Paper 6 with Wil Vreezen was written by her, partly based on my Master's thesis in Genetics; because the Staff of the Department did not believe the results, she did it all over again, and came to the same conclusions ... I never knew about the paper until I got the reprints!

The papers 15 and 20 were written by Van Steenis without the knowledge of the co-authors! No doubt, he meant well, but he could have told us! I only saw them when in proof and did not very much like what I saw. Emmy van Nieuwkoop, his devoted secretary for many years, said I could change what I thought fit, for Van Steenis never read these things again, and, in the unlikely case that he did, it would be too late, anyway. I never got any flack.

The joint papers with Ben Stone (28) and Peter Stevens (39) were written by them, based on our correspondence. 
1960

0-1/3. Veldkamp JF. 1960. Amerikaanse ervaringen van Nederlands student. Algemeen Handelsblad 24 September. - 3 issues: 24 Sept, 1 Oct, 8 Oct.

1966

1a. Veldkamp JF. 1966. Averrhoaceae. In: Willis JC (Airy Shaw HK, ed.), A dictionary of the flowering plants and ferns, ed. $7: x x i, 109,279$, $330,638,1003$

1968

2. Veldkamp JF. 1968. A revision of Sarcotheca BI. and Dapania Korth. (Oxalidaceae). Blumea 15: 519-543.

3. Veldkamp JF. 1968. Oxalidaceae. Identif. Lists Males. Specimens 33: $489-501$.

4. Veldkamp JF. 1968. A synopsis of the genus Enicostema BI., nom. cons. (Gentianaceae). Blumea 16: 133-136.

5. Veldkamp JF. 1968. Revalidation of the African Biophytum helenae Busc. \& Muschler (Oxalidaceae). Blumea 16: 137-138.

6. Vreezen WJ, Veldkamp JF. 1969. Selection and temperature effects on extra dorsocentral bristles in Drosophila melanogaster. Genetica 40: $19-39$.

1970

7. Van der Meijden R, Veldkamp JF. 1970. Drie voor Nederland nieuwe Amaranthaceae uit de geslachten Gomphrena en Alternanthera. Gorteria 5: 54-60.

8. Veldkamp JF. 1970. Oxalidaceae. FI. Thailand 2: 16-23.

1971

9. Veldkamp JF. 1971. Enige opmerkingen over de aanpassing van de Zeeraket (Cakile maritima Scop.) aan het strand. Gorteria 5: 227-231.

10. Monod de Froideville C(, Veldkamp JF). 1971. Notes on Malesian grasses. IV. A synopsis of Centotheca and reduction of Ramosia. Blumea 19: 57-60.

11. Veldkamp JF. 1971. Notes on Malesian grasses. V. New species and combinations in Pheidochloa, Hyparrhenia, and Leptochloa. Blumea 19: 61-64.

12. Veldkamp JF. 1971. Alternanthera paronychioides St. Hil. (Amaranthaceae) in Indo-Malesia. Blumea 19: 167-169.

1972

13. Veldkamp JF. 1972. Oxalidaceae. FI. Males., Ser. I, 7: 151-178.

14. Veldkamp JF. 1972. (Review). Gilliland HB, with contributions by Holttum RE, Bor NL, edited by Burkill HM, A revised flora of Malaya, vol. 3, Grasses of Malaya. FI. Males. Bull. 26: 2055-2056.

15. Bakhuizen van den Brink Jr RC, Van Steenis CGGJ, Veldkamp JF. 1972. Amaranthaceae. FI. Males., Ser. I, 6: 915-917.

16. Veldkamp JF. 1973. A botanical expedition to Mt. Suckling (Goropu Mountains), Papua New Guinea, 1972: 11 pp. Mimeograph, Rijksherbarium, Leiden.

17. Veldkamp JF. 1973. A revision of Digitaria Haller (Gramineae) in Malesia. Blumea 21: 1-80 (Thesis).

18. Van Steenis CGGJ, Veldkamp JF. 1973. Note on Houttuyn's herbarium. Blumea 21: 151-152.

1b. Veldkamp JF. 1973. Id., ed. 8 (1973) 112, 286, 338, 655, 1030

1974

19. Veldkamp JF. 1974. A taxonomic revision of Dichelachne Endl. (Gramineae) with some new combinations in Stipa L. and Oryzopsis Michx. Blumea 22: 5-12.

20. Lavaleye M, Veldkamp JF. 1974. A note on Neptunia Lour. (Leguminosae) in Malesia. Blumea 22: 168-169.

1975

21. Veldkamp JF. in F. Fijten. 1975. A taxonomic revision of Buergersiochloa Pilg. (Gramineae). Blumea 22: 418.

1976

22. Veldkamp JF. 1976. Panicum ciliatum Ell. (Gramineae) has to be called P. leucoblepharis Trin. Taxon 25: 185-186.

23. Touw A, Veldkamp JF. 1976. Een botanische expeditie naar de Star Mountains, Papua New Guinea, 1975: $13+2$ pp. Mimeograph, Rijksherbarium, Leiden.
24. Veldkamp JF. 1976. Proposal for the conservation of Echinochloa Beauv. (1812) (Gramineae) against Tema Adanson (1763) and Ornithospermum Dumoulin (1782), non Ornithosperma Raf. (1817) (Convolvulaceae). Taxon 25: 363-364.

25. Veldkamp JF. 1976. Digitaria (Gramineae). Identif. Lists Males. Specimens 52: 938-952. Mimeograph, Rijksherbarium, Leiden.

26. Veldkamp JF. 1976. Cyperaceae, Gramineae, Geraniaceae. In: Hope GS, et al. 1976. The equatorial glaciers of New Guinea: 156-158, 161.

1977

27. Veldkamp JF. 1977. A new Juncus from New Guinea (Juncaceae) Blumea 23: 415-416. - 'nupela' is Pidgin, meaning 'new'.

28. Stone BC, Bowen HJM, Veldkamp JF. 1977. European weeds introduced to Gunung Ulu Kali, Genting Highlands, Pahang. Malayan Nat. J. 30: 103-108

1978

29. Veldkamp JF. 1978. A botanical trip to the Burgers Mt. and Mt. Kegum, Papua New Guinea, 1977: 28 pp. Mimeograph, Rijksherbarium, Leiden.

30. Veldkamp JF. 1978. A proposal to reject the name Alternanthera ficoidea (Linne) Beauv. (Amaranthaceae) in favour of A. tenella Colla. Taxon 27: 310-314

31. Veldkamp JF. 1978. The identity of Digitaria leptalea and its variety (Gramineae). Acta Phytotax. Geobot. 29: 178.

32. Veldkamp JF, Franken NAP, Roos MC, Nayar MP. 1979. A revision of Diplectria (Melastomataceae). Blumea 24: 405-430.

33. Veldkamp JF, Nayar MP. 1979. The synonymy of the species in Anplectrum (Melastomataceae). Blumea 24: 431-435.

34. Veldkamp JF. 1979. Notes on Creochiton, Dissochaeta, and Macrolenes (Melastomataceae). Blumea 24: 437-446.

35. Veldkamp JF. 1979. The Medinilla myrtiformis-alliance (Melastomataceae). Blumea 24: 447-454.

36. Veldkamp JF, Moerman A. 1979. A review of the Malesian species of Geranium L. (Geraniaceae). Blumea 24: 463-477.

37. Veldkamp JF. 1979. Obituary. Monod de Froideville, Charles (31.v.1896 -21.xi.1978). FI. Males. Bull. 32: 3180-3183

38. Veldkamp JF. 1979. A new Vaccinium (Ericaceae) from Papua New Guinea. Blumea 25: 479-480.

39. Stevens PF, Veldkamp JF. 1979. The Mt. Suckling Expedition of 1972 Bot. Bull., Lae 10: iv, 36 pp.

1980

40. Veldkamp JF. 1980. Poaceae, p.p. in P. van Royen. 1980. Alpine flora of New Guinea 2: 1035-1152.

41. Veldkamp JF. 1980. The Rijksherbarium at 150 years. Taxon 29 101-104

42. Veldkamp JF. 1980. Conservation of Notodanthonia Zotov (Gramineae). Taxon 29: 293-298.

43. Veldkamp JF. 1980. Setaria clivalis (Ridl.) Veldk., comb. nov. (Gramineae). Liber gratulatorius in honorem H.C.D. de Wit. Misc. Pap. Landbouwhogeschool Wageningen 19: 315-320.

44. Veldkamp JF. 1980. Notes on Malesian grasses. VII. Chikusichloa, Digitaria. Blumea 26: 387-392.

45. 't Hart E, Veldkamp JF. 1980. A revision of Elaeagnus (Elaeagnaceae) in Malesia. Blumea 26: 393-401.

46. Veldkamp JF. 1981. Pseudodissochaeta spirei (Guill.) Veldk. \& Maxwell. In: Maxwell JF, Taxonomic notes on the tribe Dissochaeteae (Naud.) Triana (Melastomataceae). Gard. Bull. Singapore 33: 324.

47. Veldkamp JF. 1981. Some notes on Alternanthera Forssk. and Froelichia Moench (Amaranthaceae) and a proposal to amend Article 48 and delete Article 69. Taxon 30: 129, 208-209.

48. Geesink R, Leeuwenberg AJM, Ridsdale CE, Veldkamp JF. 1981. Thonner's analytical key to the families of flowering plants. Leiden Bot. Ser. 5: xxvi, 231 pp. Electronically available at http://www.hoefsmid26.nl/thonner/start.html.

49. Veldkamp JF. 1981. Validation of Blakeochloa Veldk. (Gramineae) Taxon 30: 477-478.

50. Geesink R, Veldkamp JF. 1981. HI-IAPT Portraits of botanists. 98. Franz Thonner. Taxon 30: 878. 
51. Van Steenis CGGJ, Veldkamp JF. 1982. Miscellaneous botanical notes. XXVI. 158. Juncus bufonius Linné (Juncaceae) on Mt. Kinabalu, Sabah. Reinwardtia 10: 21-27.

52. Veldkamp JF. 1982. Agrostis (Gramineae) in Malesia and Taiwan. Blumea 28: 199-228.

53. Veldkamp JF. 1982. Cruciferae, Saxifragaceae. In: Van Steenis CGGJ, Critical notes on New Guinea plants described by A. Gilli. Blumea 28: 166, 169.

54. Veldkamp JF. 1982. Agrostis valvata Steud. is the correct name for Agrostis nipponensis (Gramineae). J. Jap. Bot. 57: 96.

55. Sevenster JG, Veldkamp JF. 1983. A revision of Helictotrichon (Gramineae) in Malesia. Blumea 28: 329-342.

56. Veldkamp JF. 1983. Nomenclature of Agathis dammara (Lamb.) L.C.M. Rich. (Araucariaceae). Acta Bot. Neerl. 32: 118.

57. Veldkamp JF. 1983. (Review). Macura P, Elsevier's Dictionary of Botany. II. general terms in English, French, German, and Russian. Acta Bot. Neerl. 33: 121-122.

58. Veldkamp JF. 1983. Proposal to conserve 5777a Astronidium A. Gray (1854) against Lomanodia Raf. (1838) (Melastomataceae). Taxon 32: $134-135$.

59. Veldkamp JF, Kalkman C. 1983. In Memoriam Dr. M. Jacobs. Mare 19 Mei 1983: 22.

60. Veldkamp JF. 1983. Proposal to conserve Trisetum (Gramineae) and its type species. Taxon 32: 487-488. - Rejected: Taxon 36: 75.

61. Veldkamp JF, Van der Have JC. 1983. The genus Trisetum (Gramineae) in Malesia and Taiwan. Gard. Bull. Singapore 36: 125-135.

62. De Koning R, Sosef MSM, Veldkamp JF. 1983. A revision of Heteropholis and Thaumastochloa (Gramineae). Gard. Bull. Singapore 36: 137-162.

63. Veldkamp JF. 1983. (Review). Hodd T, Hodd P, Grasses of Western India. FI. Males. Bull. 36: 3946.

64. Veldkamp JF. 1983. (Review). Cope ThA, Poaceae. In: Nasir E, Ali SI, Flora of Pakistan 143 (1982). FI. Males. Bull. 36: 3980.

1984

65. Veldkamp JF. 1984. The identity of Andropogon nutans Linnaeus (Gramineae). Taxon 33: 95-97

66a. Veldkamp JF. 1984. Ericaceae. In: Van Steenis CGGJ, et al., Miscellaneous botanical notes. XXVII. Blumea 29: 401.

66b. Veldkamp JF. 1984. Gramineae. In: Van Steenis CGGJ, et al., Miscellaneous botanical notes. XXVII. Blumea 29: 403.

66c. Veldkamp JF. 1984. Records from the Latimodjong Mts., Central Celebes. In: Van Steenis CGGJ, et al., Miscellaneous botanical notes. XXVII. Blumea 29: 405

66d. Veldkamp JF. 1984. Cerastium in New Guinea. In: Van Steenis CGGJ, et al., Miscellaneous botanical notes. XXVII. Blumea 29: 406.

67. Veldkamp JF, De Laubenfels DJ. 1984. Proposal to reject Pinus dammara (Araucariaceae). Taxon 33: 337-347. - Defeated: Taxon 36: 736 .

68. Veldkamp JF. 1984. Dear Dr. Harvey. In: Brummitt RK, Taylor NP (compilers), Nomenclatural Forum. 6: 45. Privately circulated.

69. Veldkamp JF. 1984. Berberidopsis (Flacourtiaceae) in Australia. Blumea 30: 21-29.

70. Veldkamp JF. 1984. A new Poa (Gramineae) from New Guinea. Blumea 30: 71-72.

71. Veldkamp JF. 1985. Anemanthele Veldk. (Gramineae: Stipeae), a new genus from New Zealand. Acta Bot. Neerl. 34: 105-109.

72. Korthof AM, Veldkamp JF. 1985 ('1984'). A revision of Aniselytron with some new combinations in Deyeuxia in S.E. Asia (Gramineae). Gard. Bull. Singapore 37: 213-223.

73. Veldkamp JF. 1985. (Review). Tsvelev NN, Grasses of the Soviet Union. Acta Bot. Neerl. 34: 247-248.

74. Veldkamp JF. 1985. (Review). Burbidge NT, Australian grasses. Acta Bot. Neerl. 34: 250

75. Schouten Y, Veldkamp JF. 1985. A revision of Anthoxanthum including Hierochloë (Gramineae) in Malesia and Thailand. Blumea 30: 319-351.

76. Veldkamp JF. 1985. Aegopogon (Gramineae) in Malesia. Reinwardtia 10: 115-117.

76a. Veldkamp JF. 1985. Material requested: De in Nederland verwilder(en)de soorten van Elaeagnus. Gorteria 12: 244

77. Veldkamp JF. 1985. (Review). Dahlgren RMT, Clifford HT, Yeo PF, The families of the Monocotyledons, structure, evolution and taxonomy. Acta Bot. Neerl. 34: 447-448.
78. Veldkamp JF. 1985. (Review). But PP-H, Chio L-C, Fung H-L, Hu S-Y, Hong Kong bamboos. Bambusblatter 4: 17-18.

368. Veldkamp JF. 1985. (Review). Grierson AJC, Long DG, Flora of Bhutan, including a record of plants from Sikkim. I, 2. FI. Males. Bull. 38: 186.

369. Veldkamp JF. 1985. (Review). Meeuse BJD, Morris S, The sex life of flowers. FI. Males. Bull. 38: 187

370. Veldkamp JF. 1985. Vogelenzang L, Guide to the prices of antiquarian and secondhand botanical books. FI. Males. Bull. 38: 192.

1986

79. Veldkamp JF. 1986. Elaeagnaceae. FI. Males., Ser. I, 10: 151-156

80. Veldkamp JF. 1986. Insecticidal properties of the Neem tree (Azadirachtha indica): it's for the birds! FI. Males. Bull. 9: 304

81. Veldkamp JF. 1986. Terrorist tactics in taxonomy, a summary. FI. Males. Bull. 9: 311-312.

82. Veldkamp JF. 1986. (Review). But PP-H, Chio L-C, Fung H-L, Hu S-Y, Hong Kong bamboos. FI. Males. Bull. 9: 315-316.

83. Veldkamp JF. 1986. (Review). Dahlgren RMT, Clifford HT, Yeo PF, The families of the Monocotyledons, structure, evolution and taxonomy. FI. Males. Bull. 9: 317-318.

84. Veldkamp JF. 1986. (Review). Leach GL, Osborne PL, Freshwater plants of Papua New Guinea. FI. Males. Bull. 9: 320.

85. Veldkamp JF, De Koning R, Sosef MSM. 1986. Generic delimitation of Rottboellia and related genera (Gramineae). Blumea 31: 281-307.

1987

86. Veldkamp JF, Rouwenhorst RJ. 1987. A revision of Evodiella (Rutaceae). Blumea 32: 195-207.

87. Veldkamp JF, Flipphi RC. 1987. A revision of Leptonychia (Sterculiaceae) in Southeast Asia. Blumea 32: 443-457.

88. Veldkamp JF. 1987. In: De Vogel EF (ed.), Manual of herbarium taxonomy and practice: 20-73, 127-157.

89. Veldkamp JF. 1987. Mimosa invisa Colla var. inermis. FI. Males. Bull. 9: 416

90. Van Steenis CGGJ, Veldkamp JF. 1987. Botanical guide to the sandy sea shores of Malesia. FI. Males. Bull. 9: 421-428.

91a. Veldkamp JF. 1987. Obituary. Reinier Cornelis Bakhuizen van den Brink. FI. Males. Bull. 9: 371-373.

91b. Veldkamp JF. 1987. Obituary. Josephine Therese Koster. FI. Males. Bull. 9: 374-375

92. Veldkamp JF. 1987. (Review). Goetghebeur P, Genera cyperacearum Een bijdrage tot de kennis van de morfologie, systematiek en fylogenese van de Cyperaceae-genera. FI. Males. Bull. 9: 439-440.

93. Veldkamp JF. 1987. (Review). Peekel PG (M.S.C.), Flora of the Bismarck Archipelago for naturalists. FI. Males. Bull. 9: 441-442.

94. Veldkamp JF. 1987. Gramineae. In: Van Steenis CGGJ, Checklist of generic names: $63-68$

1988

95. Gideon OG, Tjitrosoedirdjo SS, Veldkamp JF. 1988. Notes on Mycetia (Rubiaceae). Floribunda 1: 17-19.

96. Saw LG, Uji T, Veldkamp JF. 1988. Notes on the Setaria palmifolia group (Gramineae) in Malesia. Floribunda 1: 21-23.

97. Veldkamp JF. 1988. Obituary. Santos, Jose Vera. FI. Males. Bull. 10: $3-5$

98. Veldkamp JF, Vink W, Frodin DG. 1988. Ledermann's and some other German localities in Papua New Guinea. FI. Males. Bull. 10: 32-38.

99. Veldkamp JF. 1988. Notes on Pteleocarpa, incertae sedis. FI. Males. Bull. 10: 47-50.

100. Veldkamp JF. 1988. (Review). George AS (ed.), Flora of Australia Vol. 45. Hydatellaceae to Liliaceae. FI. Males. Bull. 10: 51-52.

101. Veldkamp JF. 1988. (Review). Grierson AJC, Long DG, Flora of Bhutan, including a record of plants from Sikkim. I, 3. FI. Males. Bull. 10: 52 .

102. Veldkamp JF. 1988. (Review). Mabberley DJ, The plant book - A portable dictionary of the higher plants. Fl. Males. Bull. 10: 53.

103. Veldkamp JF. 1988. (Review). Maxwell JF, et al. 1987. Weeds of plantations crops in Southern Thailand. FI. Males. Bull. 10: 53-54.

104. Veldkamp JF. 1988. (Review). Rosengarten Jr F. 1984. The book of edible nuts. FI. Males. Bull. 10: 55

105. Veldkamp JF. 1988. (Review). Soerjani M, et al. (eds.). 1986. Weeds of rice in Indonesia. FI. Males. Bull. 10: 56

106. Veldkamp JF. 1988. (Review). Van Steenis CGGJ. 1987. Checklist of generic names in Malesian botany (Spermatophytes). FI. Males. Bull. 10: 56-57. 
107. Veldkamp JF. 1988. (Review). Uhl NW, Dransfield J. 1987. Genera palmarum. A classification of palms based on the work of Harold $\mathrm{E}$. Moore Jr. FI. Males. Bull. 10: 57-58.

108. Meijer W, Veldkamp JF. 1988. A revision of Rhizanthes (Rafflesiaceae). Blumea 33: 329-342.

109. Veldkamp JF. 1988. The Medinilla myrtiformis-alliance. II. (Melastomataceae). Blumea 33: 509.

110. Veldkamp JF. 1989. A Dutchman's view of 'copynii'. In: Brummitt RK, Taylor NP (compilers), Nomenclatural Forum 20: 149. Privately circulated.

111. Veldkamp JF. 1989. Notes on Biophytum (Oxalidaceae) of the Old World. Taxon 38: 110-116, 1 tab. (based on msc. of Heleen M. van de Klift)

112. Veldkamp JF, Scholz H. 1989. The identity of Panicum tenellum Lam. (Gramineae). Bull. Mus. Natl. Hist. Nat., Paris, IV, 10, B, Adansonia: 435-436.

113. Veldkamp JF, Van Scheindelen HJ. 1989. Australopyrum, Brachypodium, and Elymus (Gramineae) in Malesia. Blumea 34: 61-76.

114. Veldkamp JF, Eijs AWM, Zoetemeyer RB. 1989. Panicum curviflorum (formerly P. trypheron) and P. sumatrense (P. miliare auct.) (Gramineae) in Southeast Asia. Blumea 34: 77-85.

115. Veldkamp JF. 1989. The correct citation of Setaria palmifolia var. blepharoneuron (Gramineae). FI. Males. Bull. 10: 142

116. Veldkamp JF. 1989. A note on Philippine collections of F.M. Blanco and A. Llanos. FI. Males. Bull. 10: 143-145.

117. Veldkamp JF. 1989. (Review). Corner EJH, Wayside trees of Malaya, ed. 3. FI. Males. Bull. 10: 150-151.

118. Veldkamp JF. 1989. (Review). Davies RA, Lloyd KM (eds.). 1988. Kew Index for 1987. FI. Males. Bull. 10: 152-153.

119. Veldkamp JF. 1989. (Review). Earl of Cranbrook (ed.), Malaysia (Key environments). FI. Males. Bull. 10: 153-156

120. Veldkamp JF. 1989. (Review). Koyama T. 1987. Grasses of Japan and its neighboring countries. FI. Males. Bull. 10: 157-158.

121. Veldkamp JF. 1989. (Review). Rauh W, Tropische Hochgebirgspflanzen. FI. Males. Bull. 10: 160-161.

122. Veldkamp JF. 1989. (Review). Rubeli K, Tropical rain forest in SouthEast Asia - A pictorial journey. FI. Males. Bull. 10: 161-162.

123. Veldkamp JF. 1989. (Review). Saldanha CJ (ed.). 1985. Flora of Karnataka. I. Magnoliaceae to Fabaceae. FI. Males. Bull. 10: 162.

124. Veldkamp JF. 1989. (Review). Taxon 37/3. Fl. Males. Bull. 10: 162164.

125. Veldkamp JF. 1989. Sparganiaceae. In: Van Steenis CGGJ, et al., Addenda, corrigenda et emendanda. FI. Males., Ser. I, 10: 718.

126. Veldkamp JF. 1989. Deyeuxia nagensis, the correct name for D. borii (Gramineae). J. Econ. Tax. Bot. 13: 74.

127. Veldkamp JF. 1990. (Review). Kew Index for 1987. Acta Bot. Neerl. 39: 122

128. Veldkamp JF. 1990. The true identity of Sporobolus poiretii (Gramineae). Taxon 39: 327-328.

129. Veldkamp JF. 1990. (Review). De Beer JH, McDermott MJ. 1989. The economic values of non-timber forest products in Southeast Asia, with emphasis on Indonesia, Malaysia and Thailand. FI. Males. Bull. 10: 250.

130. Veldkamp JF. 1990. (Review). Borrell OW. 1989. An annotated check-list of the flora of Kairiru Island, New Guinea. FI. Males. Bull. 10: $250-251$.

131. Veldkamp JF. 1990. (Review). Forman LL, Bridson D. 1989. The herbarium handbook. FI. Males. Bull. 10: 251.

132. Veldkamp JF. 1990. (Review). Holm-Nielsen LB, Nielsen IC, Balslev $\mathrm{H}$ (eds.). 1989. Tropical forests, botanical dynamics, speciation and diversity. FI. Males. Bull. 10: 251-253.

133. Veldkamp JF. 1990. Sporobolus rigidifolius and S. mauritianus (Gramineae). Kew Bull. 45: 581-582.

134. Veldkamp JF. 1990. Sporobolus indicus (L.) R.Br. var. indicus (Gramineae) en Gironde, France. Bull. Soc. Sci. Nat. O. France, n.s. 12: 79-80.

135. Maxwell JF, Veldkamp JF. 1990. Notes on the Astronieae (Melastomataceae). - I. Astrocalyx, Astronia. Blumea 35: 71-114.

136. Maxwell JF, Veldkamp JF. 1990. Notes on the Astronieae (Melastomataceae). - II. Astronidium, Beccarianthus. Blumea 35: 115-164

137. Veldkamp JF. 1990. Bromus luzonensis Presl is the correct name for Bromus breviaristatus Buckl. (Gramineae). Taxon 39: 660.

138. Veldkamp JF. 1990. (Review). Davis PH, Cullen J, The identification of flowering plant families, 3rd edition. Acta Bot. Neerl. 39: 411.
139. Baaijens GJ, Veldkamp JF. 1991. Sporobolus (Gramineae) in Malesia Blumea 35: 393-458.

140. Veldkamp JF, Kreffer LA. 1991. Notes on Southeast Asian and Australian Coreopsidinae (Asteraceae). Blumea 35: 459-482.

141. Veldkamp JF, Eriks M, Smit SS. 1991. Bromus (Gramineae) in Malesia. Blumea 35: 483-497.

142. Veldkamp JF. 1991. Notes on Ericaceae from Papua New Guinea Blumea 36: 161-164.

143. Veldkamp JF. 1991. Papuacalia (Compositae), a new genus for the woody Senecios of New Guinea. Blumea 36: 165-178.

144. Veldkamp JF. 1991. Miscellaneous notes on Southeast Asian Gramineae. VI. Blumea 36: 179-181.

145. Van Steenis-Kruseman MJ, Veldkamp JF. 1991. Van Breda's Genera et species orchidearum fasc. IIII effectively published. FI. Males. Bull. 10: $331-334$

146. Veldkamp JF. 1991. Addresses of herbaria in Malesia. FI. Males. Bull. 10: $339-342$.

147. Veldkamp JF. 1991. (Review). Holmgren PK, et al. (eds.). 1990. Index herbariorum. Part I: the herbaria of the world. Ed. 8. FI. Males. Bull. 10: $345-346$.

148. Veldkamp JF. 1991. (Review). Keng H. 1990. The concise flora of Singapore. Gymnosperms and dicotyledons. FI. Males. Bull. 10: 346-347.

149. Veldkamp JF. 1991. (Review). Latiff A (ed.), Status of herbaria in Malaysia. FI. Males. Bull. 10: 348.

1992

150. Veldkamp JF, Van Steenbergen H. 1992. Perotis Aiton (Gramineae) in Australia and Southeast Asia. Austrobaileya 3: 609-614.

151. Veldkamp JF. 1992. Notes on Australian Coreopsidinae (Compositae). Austrobaileya 3: 741-744.

152. Veldkamp JF. 1992. Addresses of herbaria in Malesia (corrections and additions). FI. Males. Bull. 11: 45.

153. Veldkamp JF. 1992. (Review). Benzing DH, Vascular epiphytes. FI. Males. Bull. 11: 54

154. Veldkamp JF. 1992. (Review). Brummitt RK, Vascular plant families and genera. FI. Males. Bull. 11: 54-55

155. Veldkamp JF. 1992. (Review). Forster PI, Bostock PD, Bird LH, Bean AR, Vineforest plant atlas for South-east Queensland. FI. Males. Bull. 11: 56 .

156. Veldkamp JF. 1992. (Review). Johnson D (ed.), Palms for human needs in Asia. FI. Males. Bull. 11: 56-57.

157. Veldkamp JF. 1992. (Review). Rijnberg TF, 's Lands Plantentuin, Buitenzorg. 1817-1992. Fl. Males. Bull. 11: 58-59.

158. Veldkamp JF. 1992. Flora Malesiana Bulletin. Index volume 10: 1-51.

159. Veldkamp JF. 1992. Miscellaneous notes on SE Asian Gramineae. VII. Blumea 37: 227-237.

1993

160. Veldkamp JF. 1993. (Book announcement). Dransfield S, The bamboos of Sabah. Blumea 37: 528.

161. Veldkamp JF. 1993. (Review). Dransfield S, The bamboos of Sabah. FI. Males. Bull. 11: 145

162. Veldkamp JF. 1993. (Review). Sunarno B, Rugayah, Flora Taman Nasional Gede Pangrango. FI. Males. Bull. 11: 150-151.

163. Veldkamp JF. 1993. Miscellaneous notes on Southeast Asian Gramineae. VIII. New species in Danthonia. Blumea 38: 217-219.

164. Meijer W, Veldkamp JF. 1993. A revision of Mitrastema (Rafflesiaceae). Blumea 38: 221-229.

165. Veldkamp JF. 1993. The Anthoxanthum horsfieldii, A. formosanum and A. japonicum complex (Gramineae) in E. Asia. J. Jap. Bot. 68: 342-347.

222. Veldkamp JF. 1993. Cenchrus. In: Jarvis CE, et al., A list of Linnaean generic names and their types. Regnum Veg. 127: 31.

166. Veldkamp JF. 1994. Geranium lucidum L., de Glanzige ooievaarsbek. Sleutelblad 1994/1: 3-4 (excl. fig.!)

167. Veldkamp JF. 1994. Deyeuxia stenophylla and D. suizanensis (Gramineae) in Malesia and Taiwan. Taiwania 38: 1-4.

168. Veldkamp JF. 1994. A new variety of Sarcotheca laxa (Oxalidaceae) from Sumatra. Blumea 38: 459-460.

169. Veldkamp JF. 1994. Poa L. (Gramineae) in Malesia. Blumea 38: 409-457.

170. Veldkamp JF. 1994. (Review). Edwards ID, Macdonald AA, Proctor J (eds.). 1993. Natural history of Seram, Maluku, Indonesia. FI. Males. Bull. 11: 301-302. 
171. Veldkamp JF. 1994. Miscellaneous notes on Southeast Asian Gramineae. IX. Setaria and Paspalidium. Blumea 39: 373-384.

172. Veldkamp JF, Nowack R. 1995. Vietnamochloa aurea (Gramineae: Eragrostideae), a new genus and species from Vietnam. Bull. Mus. Natl. Hist. Nat. IV, 16, B, Adansonia: 213-218.

173. Veldkamp JF. 1995. (Review). Green PS. In: Orchard AE, Wilson AJG (eds.). 1993. Flora of Australia 50. Oceanic Islands 1. FI. Males. Bull. 11: 430.

174/ Veldkamp JF. 1995. (Review). Harriman NA (ed.), Gramineae. In:

175 Dassanayake MD, Fosberg FR, Clayton WD (eds.). 1994. FI. Males. Bull. 11: 430-431; Id., 1994. Blumea 40: 362.

176. Veldkamp JF. 1995. (Review). Newman MF, Burgess PF, Whitmore TC. 1995. Manuals of Dipterocarps for foresters - Singapore. FI. Males. Bull. 11: 432-433.

177. Veldkamp JF, Van Donkelaar R, Kloppenburg RD. 1995. The identity of Sperlingia Vahl (Asclepiadaceae). Blumea 40: 425-428; reprinted in Fraterna, 1st Quart. 1996: 3-5.

1996

-. Beaman JH, Beaman RS, Dransfield S, Veldkamp JF. 1998. Poaceae. The plants of Mount Kinabalu 3: 151-175. Natural History Publications (Borneo), Kota Kinabalu. $=377$

178. Veldkamp JF. 1996. Proposal to conserve the name Brachiaria (Trin.) Griseb. (Gramineae) with a conserved type. Taxon 45: 319-320. Rejected: Brummitt, Taxon 47 (1998) 869.

179. Veldkamp JF. 1996. Panicum, Whiteochloa (Gramineae: Paniceae) in Malesia. Blumea 41: 181-216.

180. Markgraf-Dannenberg I, Veldkamp JF. 1996. Festuca L. (Gramineae) in Malesia. Blumea 41: 217-222.

181. Veldkamp JF. 1996. DELTA, Snowdenia, of Met-de-PC-gaat't-vlugger. Muurkrant September 1996: 6-7.

182. Veldkamp JF. 1996. Name changes in Agrostis, Arundinella, Deyeuxia, Helictotrichon, Tripogon (Gramineae). Blumea 41: 407-411.

183. Veldkamp JF. 1996. Brachiaria, Urochloa (Gramineae - Paniceae) in Malesia. Blumea 41: 413-437.

184. Veldkamp JF, Hansen B. 1996. New combinations under Hoya verticillata (Vahl) G. Don (Asclepiadaceae) and a bibliographical note on Sperlingia Vahl. Blumea 41: 439-442.

185. Veldkamp JF. 1997. Overlooked genera and species in the Malesian flora: the case of Crocosmia (Iridaceae) and some others. FI. Males. Bull. 11: 511-514

186. Veldkamp JF. 1997. The correct name for Archidendron clypearia (Jack) Nielsen var. casai (Blanco) Nielsen (Leguminosae - Mimosoideae). FI. Males. Bull. 11: 515-517.

187. Veldkamp JF. 1997. (Review). Thornton I. 1996. Krakatau, the destruction and reassembly of an island ecosystem. FI. Males. Bull. 11: 523-524.

188. Veldkamp JF. 1997. (Review). Walsh NG, Entwisle TJ (eds.). 1994. Flora of Victoria. Volume 2. Ferns and allied plants, conifers and monocotyledons. FI. Males. Bull. 11: 524-526; Blumea 42: 259-260.

189. Veldkamp JF. 1997. (Review). Wong KM. 1995. The morphology, anatomy, biology and classification of Peninsular Malaysian bamboos. \& Wong KM. 1995. The bamboos of Peninsular Malaysia. FI. Males. Bull. 11: 526-527.

190. Veldkamp JF. 1997. (Review). International code of nomenclature of cultivated plants, ed. 6. FI. Males. Bull. 11: 527.

191. Veldkamp JF. 1997. (Review). Grubben GJH, Partohardjono S (eds.), Cereals. PROSEA Volume 10. Blumea 42: 260.

192. Veldkamp JF. 1997. The herbaceous bamboos in Malesia. In: Chapman GP, The bamboos. Linnean Society Symposium Series 19: $147-160$.

193. Willemsen MA, Veldkamp JF. 1997. (Obituary). Verheijen, Jilis Antonius Josephus. Zevenaar, The Netherlands, 26 March 1908 - Teteringen, The Netherlands, 25 April 1997. FI. Males. Bull. 12: 30-31.

194. Veldkamp JF. 1997. (Review). Dassanayake MD, Clayton WD (eds.). 1997. A revised handbook to the Flora of Ceylon. XI. FI. Males. Bull. 12: 55-56.

195. Veldkamp JF. 1997. (Review). Hanum IF, Van der Maesen LJG (eds.). 1997. Auxiliary plants. PROSEA 11. FI. Males. Bull. 12: 57.

196. Veldkamp JF. 1997. (Review). Lemmens RHMJ, Soerianegara I, Wong WC (eds.). 1995. Timber trees: minor commercial timbers. PROSEA 5 (2). FI. Males. Bull. 12: 58-59.

197. Veldkamp JF. 1997. (Review). MacKinnon K, Hatta G, Halim H, Mangalik A. 1996. The ecology of Kalimantan. The ecology of Indonesia Series 3. FI. Males. Bull. 12: 59-60.

1998

198. Veldkamp JF. 1998. Groot hoefblad [Petasites hybridus (L.) Gaertn. B.Mey. \& Scherb., Compositae] is niet Nederlands. KNNV Nieuwsbrief 34: 3-4. - See 204

199. Veldkamp JF. 1998. The Dutch 'long y' or 'y-with-dots' (ij), or, when is the $\mathrm{j}$ a vowel when a consonant? In: Brummitt RK, Challis CM (compilers), Nomenclatural Forum 32: 230. Privately circulated.

200. Hacker JB, Phimphachanhvongsod V, Novaha S, Kordravang P, Veldkamp JF, Simon BK. 1998. A guide to the grasses of Xieng Khouang Province, Lao PDR, and some notes on ecology of grazing lands in the province. Genetic Resources Communication 28. 89 pp, illus.

201. Veldkamp JF, Sosef MSM. 1998. A proposal regarding isonyms. Taxon 47: 491-492.

202. Adams RP, Zong M, Turuspekov Y, Dafforn MR, Veldkamp JF. 1998. DNA fingerprints reveal clonal nature of Vetiveria zizanioides (L.) Nash, Gramineae, and sources of potential new germplasm. Molec. Ecol. 7: 813-818.

203. Veldkamp JF. 1998. Het Kameleon in toga (si non e vero e ben trovato). In: Batenburg J, et al., Lustrumboek Leidse Biologen Club, 1923-1998, Eindeloos: 155-158.

204. Veldkamp JF. 1998. Groot hoefblad [Petasites hybridus (L.) Gaertn., B.Mey. \& Scherb., Compositae] is niet Nederlands. Venkraai 142: 9-14. - Annotated reprint of 198.

205. Veldkamp JF. 1998. (Review). Van Balgooy MMJ. 1998. Malesian seed plants. Volume 2. - Portraits of tree families. FI. Males. Bull. 12: 179 .

206. Veldkamp JF. 1998. (Review). Kochummen KM. 1997. Tree flora of Pasoh Forest. FI. Males. Bull. 12: 179-180.

207. Veldkamp JF. 1998. Poaceae, other grasses. In: Beaman JH, Beaman RS, The plants of Mount Kinabalu. 3. Gymnosperms and non-orchid monocotyledons: 151-175.

208. Veldkamp JF. 1998. Exbucklandia vs. Symingtonia (Hamamelidaceae). Rheedea 8: 159-161.

377. Beaman JH, Beaman RS, Dransfield S, Veldkamp JF. 1998. Poaceae. The plants of Mount Kinabalu 3: 151-175. Natural History Publications (Borneo), Kota Kinabalu.

1999

209. Veldkamp JF. 1999. New records of Gramineae for Malesia. FI. Males. Bull. 12: 231-239.

210. Veldkamp JF. 1999. (Obituary). Van Steenis-Kruseman, Maria Johanna. FI. Males. Bull. 12: 253-255.

211. Thijsse G, Veldkamp JF. 1999. The Van Royen Herbarium on microfiche. Folder: [2-3]. Index [2-3] with different text (earlier version). * Thijsse G, Veldkamp JF, Idc Publishers. 1999. Microfiched. The Van Royen Herbarium, so important for nomenclature and typification. Taxon 48: 629. doi: https://doi.org/10.2307/1224605.

212. Veldkamp JF. 1999. Eupatorium catarium, a new name for Eupatorium clematideum Griseb., non Sch. Bip. (Compositae), a S American species naturalized and spreading in SE Asia and Queensland, Australia. Gard. Bull. Singapore 51: 119-124.

213. Veldkamp JF. 1999. Digitaria effusa Veldk. (Gramineae), a new species from Vietnam. Blumea 44: 447-448.

214. Hacker JB, Trang T-K, Veldkamp JF. 1999. A guide to the grasses of grazing lands in Central Vietnam and some notes on their ecology. Genetic Resources Communication 34: 1-90.

215. Veldkamp JF. 1999. (Review). Keng H, Chin SC, Tan HTW. 1998. The concise Flora of Singapore. Volume 2: Monocotyledons. FI. Males. Bull. 12: 290

216. Veldkamp JF. 1999. (Review). Radcliffe-Smith A. 1998. Three-language list of botanical name components. Fl. Males. Bull. 12: 290-291.

217. Veldkamp JF. 1999. A revision of Chrysopogon Trin. and Vetiveria Bory (Gramineae) in Thailand and Malesia with notes on some other species from Africa and Australia. Austrobaileya 5: 503-533.

218. Wipff JK, Veldkamp JF. 1999. Pennisetum advena sp. nov. (Poaceae: Paniceae): a common ornamental throughout the southern United States. Sida 18: 1031-1036.

219. Veldkamp JF. 2000. Je kan dit vak ook aan niemand toevertrouwen! Muurkrant (internal bulletin) Februari 2000: 14-15. 
220. Veldkamp JF. 2000. Een enkele reis Paradijs? Muurkrant (internal bulletin) Mei 2000: 21-23.

221. Veldkamp JF. 2000. In: Cafferty S, Jarvis CE, Turland NJ (eds.), Typification of Linnaean plant names in the Poaceae. Taxon 49: 239-260.

223. Veldkamp JF. 2000. (Review). Lack W, Mabberley DJ. 1999. The Flora Graeca story. Sibthorp, Bauer, and Hawkins in the Levant. Blumea 45: $250-251$.

224. Veldkamp JF. 2000. C.A. Backer, schrijver van een uniek woordenboek. In: Backer CA, Verklarend woordenboek van wetenschappelijke plantennamen, 2e druk: ix-xxi.

225. Veldkamp JF. 2000. C.A. Backer, Review. Verklarend woordenboek van wetenschappelijke plantennamen (1936). Muurkrant Oktober 2000: 13-14, illus.

225a. Trainor C, Veldkamp JF. 1997. In memory of Father Jilis A.J. Verheijen

252. (1908-1997). Kukila 11: 179-181.

226. Van den Heuvel E, Veldkamp JF. 2000. Revision of Hemarthria (Gramineae-Andropogoneae-Rottboelliinae). Blumea 45: 443-475.

227. Veldkamp JF. 2000. (Review). Edgar E, Connor HE, Flora of New Zealand. Volume V. Grasses. Blumea 45: 495.

228. Veldkamp JF. 2000. (Review). Noltie HJ, Flora of Bhutan, including a record of plants from Sikkim and Darjeeling. Volume 3, Part 2: The grasses of Bhutan. Blumea 45: 498-499.

229. Veldkamp JF, Salunkhe CB. 2000. Chrysopogon castaneus (Gramineae-Andropogoneae), a new species from Maharashtra, India. Rheedea 10: 59-61.

2001

230. Veldkamp JF. 2001. Flora Malesiana Bulletin. Index - Volume 12, 1997-2001: 62 pp.

231. Veldkamp JF. 2001. A short biography of C.A. Backer, nestor of the Flora of Java. FI. Males. Bull. 12: 364-376.

232. Veldkamp JF. 2001. (Review). Straver H, Boelens A, Atlas Maluku. FI. Males. Bull. 12: 404.

233. Veldkamp JF. 2001. Editor's note to F.S.P. Ng, Diospyros and the myth of the forbidden fruit. Fl. Males. Bul. 12: 399.

234. Buitenhuis AG, Veldkamp JF. 2001. Revision of Eremochloa (Gramineae - Andropogoneae - Rottboelliinae). Blumea 46: 399-420.

235. Veldkamp JF. 2001. The identity of three American species of Chloris Sw. (Gramineae) described from the Philippines by P. Durand (1808). Taxon 50: 845-852.

236. Veldkamp JF. 2001. Weeds, plants of the future. Malayan Nat. J. 55: 187-195.

237. Veldkamp JF. 2001. Cocos lucifera (Glow palm) another member of the Poleaceae (Telecomicaceae). BSBI News 88: 15.

238. Bodegom S, Veldkamp JF. 2001. A revision of the pseudo-stipular species of Medinilla Gaud. ex DC. (Melastomataceae-Melastomatoideae-Miconieae). Blumea 46: 527-567.

239. Turner H, Veldkamp JF. 2001. Parnassia (Parnassiaceae) in N Sumatra. Blumea 46: 599-603.

240. Veldkamp JF. 2001. Leading the sighted. New Scientist 2318 (24 November): 113.

326. Peterson PM, Boechat SC, Veldkamp JF. 2001. Sporobolus. In: Catalogue of New World Grasses (Poaceae): II. Subfamily Chloridoideae. Contr. U.S. Natl. Herb. 41: 200-219.

2002

241. Veldkamp JF. 2002. 15 June 2002, 300th anniversary of Rumphius' death. Fl. Males. Bull. 13: 7-21.

242. Veldkamp JF. 2002. A revision of Eragrostis (Gramineae, Chloridoideae) in Malesia. Blumea 47: 157-204.

243. Nowack R, Veldkamp JF. 2002. Notes on Lepturus (Gramineae) in Malesia. Blumea 47: 385-389.

244. Jannink TA, Veldkamp JF. 2002. Revision of Chionachninae (Gramineae: Andropogoneae). Blumea 47: 545-580.

245. Veldkamp JF. 2002. (Review). Ravi N, Mohandan N, Common tropical and subtropical sedges and grasses. Blumea 47: 696-697.

246. Veldkamp JF. 2002. Mestica calappa, the coconut pearl, trick or true? FI. Males. Bull. 13: 143-153.

2003

247. Veldkamp JF. 2003. Nomenclature of Syzygium gracile (Myrtaceae). Blumea 48: 489-490.

248. Veldkamp JF, Phillips SM. 2003. Tripogon (Gramineae) in Thailand. Blumea 48: 491-494.

249. Veldkamp JF. 2003. Miscellaneous notes on Thai Gramineae. Blumea 48: 495-501.

250. Veldkamp JF. 2003. (Review). A guide to ... Fl. Males. Bull. 13: 284.
251. Veldkamp JF. 2003. (Review). Kress WJ, DeFilipps R, Farr E, Daw Yin Yin Kyi. 2003. A checklist of the trees, shrubs, herbs, and climbers of Myanmar. FI. Males. Bull. 13: 284-286.

2004

253. Veldkamp JF. 2004. Bilimbia (Lichenes) resurrected. The Lichenologist 36: 191-195.

254. Veldkamp JF. 2004. Miscellaneous notes on mainly Southeast Asian Gramineae. Reinwardtia 12: 135-140.

255. Iskandar EAP, Veldkamp JF. 2004. A revision of Malesian Isachne sect. Isachne (Gramineae, Panicoideae, Isachneae). Reinwardtia 12 159-179.

256. Veldkamp JF. 2004. The correct name for Pyrrosia hastata Ching (Polypodiaceae, Pteridophyta). Reinwardtia 12: 191-193.

2005

257. Lut CWJ, Veldkamp JF. 2005. Guide to plant species descriptions published in seed lists from botanical gardens for the period 1800 1900. Taxon 54: 567-568.

258. Veldkamp JF. 2005. (Review). Mallett K (ed.). 2005. Flora of Australia Volume 44B. Poaceae 3. Blumea 50: 374.

259. Veldkamp JF. 2005. Leech repellents? FI. Males. Bull. 13: 371-372

260. Veldkamp JF. 2005. (Review). Duistermaat H, Field guide to the grasses of Singapore (excluding the bamboos). Gard. Bull. Singapore 57: 185-186.

2006

261. Pelser P, Veldkamp JF, Van der Meijden R. 2006. New combinations in Jacobaea Mill. (Asteraceae - Senecioneae). Compositae Newslett. 44: 1-11.

262. Veldkamp JF. 2006. (Review). Frey L (ed.), Problems of grass biology. Blumea 51: 146.

2007

263. Veldkamp JF. 2007. Ludwigia sedoides (Onagraceae) in Malesia. FI. Males. Bull. 14: 27-29.

264. Duk MAN, Veldkamp JF. 2007. Notes on Trigonotis (Boraginaceae) in Celebes. FI. Males. Bull. 14: 32.

265. Veldkamp JF. 2007. The weal and woe of Roxburghia (Stemonaceae). FI. Males. Bull. 14: 43-49.

266. Veldkamp JF. 2007. Some notes on the cultivation of Rafflesia. FI. Males. Bull. 14: 50-53.

267. Veldkamp JF. 2007. (Review). Buijze W, Leven en werk van Georg Everhardus Rumphius (1627-1702). Een natuurhistoricus in dienst van de VOC. FI. Males. Bull. 14: 57.

268. Veldkamp JF. 2007. (Review). Loderichs M. 2004. Rumphius' wonderwereld. Zeventiende-eeuwse natuurbeschrijvingen uit Ambon. FI. Males. Bull. 14: 59-60.

269. Veldkamp JF. 2007. (Review). Ng FSP. 2006. Tropical horticulture and gardening. FI. Males. Bull. 14: 60-62.

270. Veldkamp JF. 2007. (Review). Nayar TS, Rasiya Beegam A, Mohanan N, Rajkumar G. 2006. Flowering plants of Kerala. Blumea 52: 204-206.

271. Sierra SEC, Kulju KKM, Veldkamp JF, Van Welzen PC. 2007. Resurrection of Hancea and lectotypification of Adisca (Euphorbiaceae). Blumea 52: 361-366.

2008

272. Veldkamp JF. 2008. De Gladde ooievaarsbek, Geranium aequale (Geraniaceae), een niet zo nieuwe soort voor Nederland? Gorteria 26: $50-57$.

273. Veldkamp JF. 2008. The correct name for the Tetrastigma (Vitaceae) host of Rafflesia (Rafflesiaceae) in Malesia and a (not so) new species. Reinwardtia 12: 261-265.

274. Jung M-J, Veldkamp JF, Kuoh C-S. 2008. Notes on Eragrostis Wolf (Poaceae) for the Flora of Taiwan. Taiwania 53: 96-102.

275. Van Welzen PC, Veldkamp JF. 2008. Trigoniaceae. FI. Thailand 9, 2: 173-175.

276. Veldkamp JF. 2008. Egeria densa (Hydrocharitaceae), a new genus and species for Malesia. FI. Males. Bull. 14: 156-159.

277. Veldkamp JF. 2008. Mestica calappa, the coconut pearl. 2. The mystery unravelled. FI. Males. Bull. 14: 160-161.

278. Esser H-J, Veldkamp JF. 2008. The Croton argyratus-complex (Euphorbiaceae) in the Malay Peninsula and Sumatra. FI. Males. Bull. 14: $166-171$.

279. Tjitrosoedirdjo SS, Veldkamp JF. 2008. Bartlettina sordida (Eupatorium sordidum) (Compositae), an invasive alien plant species in the Gede Pangrango National Park, West Java, Indonesia. FI. Males. Bull. 14: 172 . 
280. Veldkamp JF, Reveal JL, Ghandi KN. 2008. (1845) Proposal to conserve Dodecatheon jeffreyi Hort. ex Van Houtte (1867) against Dodecatheon jeffreyanum K. Koch (1866; Primulaceae). Taxon 57: 1004-1006.

281. Veldkamp JF. 2008. Press release: Godinnengras / Goddess grass. Mare 32, 7: 7 / 10. (On Lakshmia venusta).

282. Veldkamp JF. 2008. Senecio cymbalarioides, S. subnudus, and S. subpeltatus, history of a muddle (Asteraceae: Senecioneae). J. Bot. Res. Inst. Texas 2: 1215-1218.

283. Santhosh Kumar ES, Radhakrishnan K, Kunhikannan C, Veldkamp JF, Mohanan CN. 2008. Rediscovery of Maesa velutina Mez (Maesaceae / Myrsinaceae) - An endemic and endangered species of the Western Ghats, India. Rheedea 18: 39-42.

284. Veldkamp JF. 2008. In goede aarde. Natnl. Geogr. Ned.-België Nov. 2008: 8 (letter to the editor)

285. Veldkamp JF. 2008. Sarcotheca lunduensis (Oxalidaceae), a new species from W. Sarawak, Malesia. Gard. Bull. Singapore 60: 69-71.

286. Veldkamp JF. 2008. Silene fissipetala (Caryophyllaceae), the correct name for S. fortunei from Continental China and Taiwan. Taiwania 53: $410-413$.

2009

287. Veldkamp JF. 2009. (Review). Gledhill D. 2008. The names of plants, ed. 4. Blumea 53: 632-634

288. Sumadijaya A, Veldkamp JF. 2009. Notes on Bothriochloa Kuntze (Gramineae: Andropogoneae) in Malesia. Reinwardtia 12: 415-417.

289. Sumadijaya A, Veldkamp JF. 2009. Vulpia (Gramineae) in Malesia. Reinwardtia 12: 343-346.

290. Veldkamp JF. 2009. Nomenclatural notes on Senecio valerianifolia. Compositae Newslett. 47: 4-7.

291. Veldkamp JF. 2009. The authorship of Bromus pubescens (Gramineae). J. Torrey Bot. Soc. 136: 137-138

292. Kumar P, Rawat GS, Veldkamp JF. 2009. (033) Proposal to broaden the scope of Art. 37.5 allowing an illustration as a type when it is "impossible" to preserve a specimen. Taxon 58: 664-665.

293. Veldkamp JF. 2009. Aegilotriticum $\times$ requenii, the correct name for Aegilops $\times$ triticoides (Gramineae). Webbia 64: 13-15

295. Neamsuvan O, Seelanan T, Veldkamp JF. 2009. A revision of the genus Bothriochloa (Poaceae) in Thailand. Gard. Bull. Singapore 61: 129-143.

296. Neamsuvan O, Seelanan T, Veldkamp JF. 2009. A revision of Hemisorghum (Poaceae, Sorghinae) in Thailand. Gard. Bull. Singapore 61: 145-149

297. Turner IM, Veldkamp JF. 2009. A history of Cananga (Annonaceae). Gard. Bull. Singapore 61: 189-204.

298. Veldkamp JF. 2009. (1906-1907) Proposals to conserve the names Engelhardia against Pterilema and E. spicata against P. aceriflorum (Juglandaceae). Taxon 58: 1012-1013.

299. Chen C-H, Veldkamp JF, Kuoh C-S, Tsai C-C, Chiang Y-C. 2009. Segregation of Leptatherum from Microstegium (Andropogoneae, Poaceae) confirmed by Internal Transcribed Spacer DNA sequences. Blumea 54: 175-180.

300. Veldkamp JF. 2009. Notes on the names of the Tetrastigma (Vitaceae) hosts of Rafflesia (Rafflesiaceae). Reinwardtia 13: 75-78.

305. Veldkamp JF. 2009. Sedum roberti, a new name for S. multiflorum R.T. Clausen (1978), non Boenn. (1829 / 1830), from Mexico (Crassulaceae). Haseltonia 15: 79.

2010

301. Neamsuvan O, Seelanan T, Veldkamp JF. 2010 ('2009'). Chrysopogon gryllus (Gramineae), a new record for Thailand. Thai Forest Bull., Bot. 37: 107-110.

302. Veldkamp JF. 2010 ('2009'). Xerochloa in Thailand. Thai Forest Bull., Bot. 37: 156-160.

294. Veldkamp JF. 2010 ('2008'). Lakshmia (Gramineae), a new genus from Sri Lanka and W India. Rheedea 18: 81-85.

303. Veldkamp JF, Potdar GC, Yadav SR. 2010 ('2008'). Notes on 3-flowered Paniceae (Poaceae) from India and the Cape Verde. Rheedea 18: 91-93.

304. Kumar P, Veldkamp JF. 2010. Pecteilis rawatii (Orchidaceae), a new species from India. Gard. Bull. Singapore 61: 335-341.

306. Veldkamp JF. 2010. Notes on indelible autographs and effective publication of Lindenia Benth. (Rubiaceae). Taxon 59: 957-958.

307. Craven LA, Danet F, Veldkamp JF. 2010. Rhododendron section Schistanthe, the scientific name for Vireya rhododendrons (Ericaceae). J. Amer. Rhododendron Soc. 64: 190-192.

308. Kartonegoro A, Veldkamp JF. 2010. Revision of Dissochaeta (Melastomataceae) in Java, Indonesia. Reinwardtia 13: 125-145.
309. Mat-Salleh M, Mahyuni R, Susatya A, Veldkamp JF. 2010. Rafflesia lawangensis (Rafflesiaceae), a new species from Bukit Lawang, Gunung Leuser National Park, North Sumatera, Indonesia. Reinwardtia 13: $159-165$.

310. Veldkamp JF, Saunders RMK. 2010. Goniothalamus tripetalus (Annonaceae), comb. nov. Reinwardtia 13: 167-169.

311. Snow N, Veldkamp JF. 2010. Miscellaneous taxonomic and nomenclatural notes for Myrtaceae. Austrobaileya 8: 177-186.

2011

312. Chen C-H, Veldkamp JF, Kuoh C-S. 2011. Supplements to the genus Microstegium Nees (Poaceae: Andropogoneae) of Taiwan. Taiwan J. Biodiv. 13: 85-91.

313. Veldkamp JF, Lanting F. 2011. Rafflesia. Plant zonder vader. E \& V Mag. 6: 118-119, illus. - This title was cooked up by the editor, René de Vos.

314. Cámara Leret, R, Veldkamp JF. 2011. A remarkable new Medinilla (Melastomataceae) from Celebes, Indonesia. Gard. Bull. Singapore 62: 213-221.

315. Veldkamp JF. 2011. The nomenclature of Uvaria velutina Roxb. ex Blume (Annonaceae). Gard. Bull. Singapore 62: 301-306.

316. Chen C-H, Veldkamp JF, Kuoh C-S. 2011. Microstegium glabratum (Brongn.) A. Camus (Poaceae, Andropogoneae), a new record for Japan, China, and Taiwan, based on morphological and molecular evidence. Taiwania 56: 111-117.

317. Craven LA, Danet F, Veldkamp JF, Goetsch LA, Hall BD. 2011. Vireya rhododendrons: their monophyly and classification (Ericaceae, Rhododendron section Schistanthe). Blumea 56: 153-158.

318. Raole VM, Desai RJ, Veldkamp JF. 2011. Ischaemum sayajiraoi, a new species of Poaceae from Gujarat, India. Kew Bull. 66: 303-306.

319. Veldkamp JF. 2011. Georg Everhard Rumphius (1627-1702), the blind seer of Ambon. Gard. Bull. Singapore 63: 1-15.

320. Sumadijaya A, Veldkamp JF. 2011. Bothriochloa (Poaceae: Andropogoneae) in Malesia. Gard. Bull. Singapore 63: 71-76.

2012

321. Veldkamp JF, Zonneveld BJM. 2012. The infrageneric nomenclature of Tulipa (Liliaceae). PI. Syst. Evol. 298: 87-92.

322. Turner IM, Veldkamp JF. 2012. William Roxburgh's Eye plant and its relevance in the nomenclature of Phaeanthus Hook.f. \& Thomson (Annonaceae). Kew Bull. 66: 1-8.

323. Sumadijaya A, Veldkamp JF. 2012. Non-bambusoid grasses (Gramineae) from Batanta and Waigeo Islands (Raja Ampat Archipelago), West Papua Province, Indonesia. Reinwardtia 13: 241-253.

324. Veldkamp JF. 2012. Koordersiochloa Merr. (Gramineae), the correct name for Streblochaete Hochst. ex Pilg. Reinwardtia 13: 299-303.

325. Veldkamp JF. 2012. Alpinia costatum Roxb. or A. cardamomummedium Roxb. (Zingiberaceae), an enigmatic species from Bangladesh. Rheedea 22: 1-4.

326. Peterson PM, Boechat SC, Veldkamp JF. 2001. Sporobolus. In: Catalogue of New World Grasses (Poaceae): II. Subfamily Chloridoideae. Contr. U.S. Natl. Herb. 41: 200-219. - I only in 2012 discovered that this contribution was attributed to me as co-author.

327. Pramod C, Pradeep AK, Veldkamp JF. 2012. Coelachne madayensis (Poaceae-Pooideae-Isachneae), a new species from Kerala, India. Gard. Bull. Singapore 64: 289-292.

328. Chen C-H, Veldkamp JF, Kuoh C-S. 2012. Taxonomic revision of Microstegium Nees sensu stricto (Andropogoneae, Poaceae). Blumea 57: 160-189.

364. Lin C-Y, Veldkamp JF, Chen C-H. 2012. Microstegium brandisii (Hook.f.) Rhind, a newly discovered grass (Poaceae) to Taiwan. Taiwan J. Biodiv. 14: 57-62.

329. Veldkamp JF. 2012. (Review). Wilson A (ed.). 2009. Flora of Australia Volume 44A, Poaceae 2: xvi, 410 pp. Blumea 57: 196-197.

2013

330. Kartonegoro A, Veldkamp JF. 2013. A revision of Creochiton (Melastomataceae). Blumea 58: 217-227.

331. Kiran Raj MS, Sivadasan M, Veldkamp JF, Alfarhan AH, Thomas J. 2013. Nanooravia, a new genus of the subtribe Dimeriinae (PoaceaePanicoideae-Andropogoneae) from India. Nordic. J. Bot. 31: 161165. - Invalid type species, as basionym is not fully cited. See 335

332. Mood JD, Prince LM, Veldkamp JF. 2013. The history and identity of Boesenbergia longiflora (Zingiberaceae) with five new, related taxa. Gard. Bull. Singapore 65: 47-95.

333. Veldkamp JF. 2013. Nomenclatural notes on Eugenia reinwardtiana (Myrtaceae) and more or less associated names. Gard. Bull. Singapore 65: 117-134. 
334. Cámara Leret R, Ridder-Numan JWA, Veldkamp JF. 2013. A revision of Heteroblemma gen. nov. (Dissochaeteae - Melastomataceae) from Malesia and Vietnam. Blumea 58: 229-240.

335. Kiran Raj MS, Sivadasan M, Veldkamp JF, Alfarhan AH, Thomas J. 2013. Validation of Nanooravia santapaui (Poaceae-PanicoideaeAndropogoneae-Dimeriinae). Nordic J. Bot. 31: 638.

336. Veldkamp JF. 2013. Nomenclatural notes on Boesenbergia Kuntze (Zingiberaceae). Philipp. J. Sci. 142: 215-221.

337. Veldkamp JF, Van den Boogaart MEB, Heidweiller J, Van der Klaauw MAF, De Koning R, Kraaijeveld AR, Sosef MSM, Strucker RCW. 2013. A revision of Mnesithea in Malesia and Thailand (Gramineae - Andropogoneae). Blumea 58: 277-292.

338. Maas PJM, Veldkamp JF, Newman MF. 2013. A new name for an endemic Jamaican species of Renealmia L.f. (Zingiberaceae). Edinburgh J. Bot. 71: 449-450.

2014

339. Baas P, Veldkamp JF. 2014. Dutch pre-colonial botany and Rumphius's Amboinese herbal. Allertonia 13: 9-19.

340. Baas P, Hovenkamp PH, Veldkamp JF. 2014. Hans Nooteboom 80 years. Blumea 59: i-ii.

341. Veldkamp JF, Verloove F. 2014. Bulbostylis thouarsii (comb. nov.) is the correct name for Scirpus puberulus Poir., non Michx. (Cyperaceae). Blumea 59: 10

342. Nicolson DH, Veldkamp JF. 2003. F.M. Blanco (1778-1845). FI. Males. Bull 13: 259-261.

342. Santhosh Kumar ES, Veldkamp JF, Shareef SM. 2014. Notes on Eugenia gracilis, E. mooniana, and E. phillyreoides (Myrtaceae). Webbia 69: 101-103.

343. Veldkamp JF. 2014. A revision of Cenchrus incl. Pennisetum (Gramineae) in Malesia with some general nomenclatural notes. Blumea 59: $59-75$.

344. Trisetopsis imberbis (Nees) Röser, A. Wölk \& Veldkamp. In: Wölk A, Röser M, Polyploid evolution, intercontinental biogeographical relationships and morphology of the recently described African oat genus Trisetopsis (Poaceae). Taxon 63: 785

345. Morrone O, Aliscioni SS, Veldkamp JF, Pensiero JF, Zuloaga FO, Kellogg EA. 2014. A revision of Old World species of Setaria (Poaceae: Panicoideae: Paniceae). Syst. Bot. Monogr. 96: 1-153.

346. Mood JD, Veldkamp JF, Prince LM. 2014. A new species and a new record of Boesenbergia (Zingiberaceae) from Thailand. Gard. Bull. Singapore 66: 207-214

347. Mood JD, Veldkamp JF, Dey S, Prince LM. 2014. Nomenclatural changes in Zingiberaceae: Caulokaempferia is a superfluous name for Monolophus and Jirawongsea is reduced to Boesenbergia. Gard. Bull. Singapore 66: 215-231.

348. Veldkamp JF. 2014. A new species of Juncus (Juncaceae) from Mt Kinabalu, Sabah - recent speciation after long-distance dispersal. Blumea 59: 142-143.

2015

349. Kiran Raj MS, Sivadasan M, Alfarhan AH, Veldkamp JF. 2015. Dimeria raviana, a new species of Poaceae from the Southern Western Ghats, India. Phytotaxa 195: 193-196.

350. Veldkamp JF. 2015. Proposal to conserve the name Calandrinia grandiflora Lindl. against Calandrinia glauca Schrad. (Montiaceae). Taxon 64: 174-175.

351. Santhosh Kumar ES, Shareef SM, Roy PE, Veldkamp JF. 2015. Clausena agasthyamalayana sp. nov. (Rutaceae) from Kerala, India. Nordic J. Bot. 33: 151-154.

352. Veldkamp JF. 2015 ('2014-2015'). De nomenclatuur van Speenkruiden (Ficaria verna Huds. s.I., Ranunculaceae). Gorteria 37: 84-116.
353. Kiran Raj MS, Sivadasan M, Veldkamp JF, Alfarhan AH, Tamimi ASMA. 2015. A revised infrageneric classification of Dimeria R.Br. (Poaceae-Andropogoneae). Bangladesh J. PI. Taxon. 22: 47-54.

354. Veldkamp JF. 2015. Arundinella (Gramineae) in Malesia with notes on other taxa and on aluminium accumulation. Blumea 59: 167-179.

355. Veldkamp JF, Teeratawatananon A, Sungkaew S. 2015. A revision of Garnotia (Gramineae) in Malesia and Thailand. Blumea 59: 229-237.

356. Veldkamp JF. 2015. Themeda barbata, the correct combination for Themeda japonica (Gramineae). J. Jap. Bot. 90: 293-297.

357. Veldkamp JF. 2015. An attempt to unravel the synonymy of Avenella flexuosa (L.) Drejer (Gramineae). PI. Diversity Evol. 131: 239-262.

358. Mahyuni R, Kusuma YWC, Wihermanto, Veldkamp JF. 2015. Notes on Rafflesia (Rafflesiaceae) in Sumatra with a new record Rafflesia gadutensis. Reinwardtia 14: 317-322.

359. Veldkamp JF, Sulastyaningsih LD. 2015. Nomenclature and typification of Musa salaccensis Zoll. ex Kurz (Musaceae). Reinwardtia 14: 299-302.

360. Veldkamp JF, Wardani W. 2015. Asplenium tenerum var. pallidum is the correct name for A. tenerum var. belangeri (Pteridophyta, Aspleniaceae). Reinwardtia 14: 303-306.

2016

361. Veldkamp JF. 2016. New status and combinations for the two East African taxa of Isachne R.Br. (Gramineae). Bot. Lett. 163: 19-24.

362. Veldkamp JF. 2016. Oproep: let op Speenkruid. Gorteria 38: 28.

363. Veldkamp JF. 2016. A revision of Themeda (Gramineae) in Malesia with a new species from Laos. Blumea 61: 29-40.

365. Mood JD, Hussain AG, Veldkamp JF. 2016. The resurrection of Boesenbergia albosanguinea (Zingiberaceae) - a new record for Langkawi Is., Malaysia, and Peninsular Thailand. Gard. Bull. Singapore 68: 109-124.

366. Mood JD, Trần Hữu Dăng, Veldkamp JF, Prince LM. 2016. Boesenbergia siphonantha - a new record for Thailand and Vietnam with notes on the molecular phylogeny. Gard. Bull. Singapore 68: 125137.

367. Veldkamp JF. 2016. The valid publication of Monolophus (Zingiberaceae) revisited. Gard. Bull. Singapore 68: 173-174.

371. Baas P, Veldkamp JF, Van Welzen PC. 2016. On the 80th birthdays of Willem J.J.O. de Wilde and Brigitta E.E. Duyfjes. Blumea 61: 85-86.

372. Veldkamp JF, Turner IM. 2016. The correct name for Schumannianthus dichotomus (Marantaceae). Kew Bull. 71, 47: 1-4

373. Veldkamp JF. 2016. A revision of Dimeria (Gramineae, Dimeriinae) in Malesia with a note on Cymbachne. Blumea 61: 207-214.

374. Veldkamp JF. 2016. A revision of Iseilema (Gramineae) in Malesia. Reinwardtia 15: 123-127.

2017

375. Wijnands DO, Heniger J, Veldkamp JF, Fumeaux N, Callmander NW. 2017. The botanical legacy of Martinus Houttuyn (1720-1798) in Geneva. Candollea 72: 155-198.

376. Veldkamp JF, Kartonegoro A. 2017. New species of Catanthera and Medinilla (Melastomataceae) from Halmahera, Indonesia, and a new name for a Medinilla from Madagascar. Reinwardtia 16: 25-30.

378. Veldkamp JF, Pradeep AK, Thoiba K. 2017. Eragrostis paniciformis (Gramineae) in India, a new record for Asia. Rheedea 27: 46-49.

- Veldkamp JF. 2017. Poa opinata (Gramineae), a new species from G. Binaiya, Ceram, Moluccas, Indonesia. Reinwardtia 16 (2): 73-75.

In print

- Van Andel TR, Mazumdar J, Barth ENT, Veldkamp JF. 2018. Possible Rumphius specimens detected in Paul Hermann's Ceylon herbarium (1672-1679) in Leiden, The Netherlands. Blumea, accepted.

- Veldkamp JF. Schmidiella, an enigmatic new genus of Gramineae from Laos. Adansonia III, accepted.

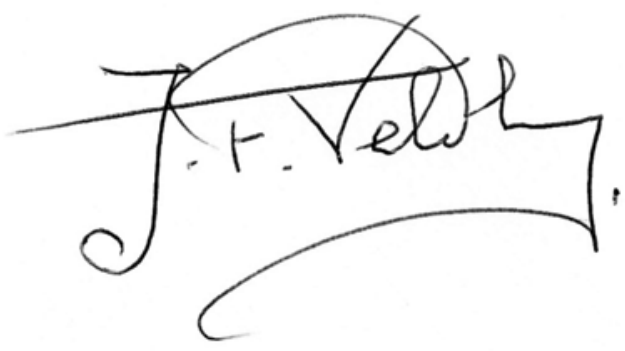

